\title{
Granulosa Cell-derived Insulin-like Growth Factor (IGF) Binding Proteins Are Inhibitory to IGF-I Hormonal Action

\author{
Evidence Derived from the Use of a Truncated IGF-I Analogue
}

\author{
E. Y. Adashi, * C. E. Resnick, * E. Ricciarelli, * A. Hurwitz, * E. Kokia, * C. Tedeschi, * L. Botero, * \\ E. R. Hernandez, ${ }^{\star}$ R. G. Rosenfeld, ${ }^{\star}$ C. Carlsson-Skwirut, ${ }^{*}$ and G. L. Francis" \\ *Division of Reproductive Endocrinology, Department of Obstetrics, Gynecology, and Physiology, University of Maryland School of \\ Medicine, Baltimore, Maryland 21201; ${ }^{\ddagger}$ Department of Pediatrics, Stanford University Medical Center, Stanford, California $94305 ;$ \\ ${ }^{\S}$ Department of Pathology, Karolinska Hospital, Stockholm S-10401, Sweden; and "Division of Human Nutrition, \\ Commonwealth Scientific and Industrial Research Organization, Adelaide SA5000, Australia
}

\begin{abstract}
An increasing body of information now suggests that insulinlike growth factor (IGF) binding proteins (BPs) may serve as antigonadotropins at the level of the ovary. It is the objective of the present communication to evaluate the functional role of endogenous (granulosa cell-derived) IGFBPs by exploiting the unique properties of des(1-3)IGF-I, a naturally occurring IGFI analogue characterized as a weak ligand of IGFBPs but not of type I IGF receptors. Given IGFBP-replete circumstances, des(1-3)IGF-I proved more potent (10-fold) than its intact counterpart in promoting the follicle stimulating hormone (FSH)-stimulated accumulation of progesterone by cultured rat granulosa cells. In contrast, des(1-3) IGF-I proved virtually equipotent to the unmodified principle under IGFBP-deplete circumstances. Taken together, these findings are in keeping with the notion and that the apparently enhanced potency of des(1-3)IGF-I (under IGFBP-replete conditions) is due to its diminished affinity for endogenously generated IGFBPs and that rat granulosa cell-derived IGFBPs are inhibitory to IGF (and thus inevitably to gonadotropin) hormonal action. Accordingly, the reported ability of gonadotropins to attenuate IGFBP release by granulosa cells may be designed to enhance the bioavailability of endogenously generated IGFs in the best interest of ovarian steroidogenesis. (J. Clin. Invest. 1992. 90:15931599.) Key words: ovary • insulin-like growth factor • insulinlike growth factor binding proteins
\end{abstract}

\section{Introduction}

Recent observations from this laboratory disclosed the multiplicity of rat (ovarian) granulosa cell-derived high affinity insulin-like growth factor (IGF) ${ }^{1}$ binding proteins (BPs) and revealed the striking ability of follicle-stimulating hormone

Address correspondence to Eli Y. Adashi, M.D., Division of Reproductive Endocrinology, Departments of Obstetrics/Gynecology and Physiology, University of Maryland School of Medicine, 405 West Redwood Street, Third Floor, Baltimore, MD 21201. 1992.

Received for publication 13 June 1991 and in revised form 6 May

1. Abbreviations used in this paper: $\mathrm{BP}$, binding proteins; $\mathrm{CM}$, amiconfiltered content of media; DES, diethylstilbestrol; IGF, insulin-like growth factor.

J. Clin. Invest.

(c) The American Society for Clinical Investigation, Inc.

0021-9738/92/10/1593/07 \$2.00

Volume 90, October 1992, 1593-1599
(FSH) to suppress their constitutive release under both in vitro and in vivo circumstances (1-3). Inasmuch as FSH is concerned with the promotion of granulosa cell development, the demonstration of FSH-attenuated IGFBP release strongly suggested that the loss of IGF binding activity may be part and parcel of granulosa cell ontogeny, an effect designed to enhance the bioavailability of endogenously generated IGFs. According to this view, soluble IGFBPs may subserve an inhibitory function by sequestering extracellular (granulosa cell-elaborated) IGFs, thereby diminishing their bioavailability. In so doing, IGFBPs may in effect be acting as antigonadotropins in that the IGFs so sequestered are precluded from amplifying the gonadotropic signal (4). That this in fact may be the case is further supported by recent observations wherein exogenously added IGFBP-1 (5), IGFBP-2 (6), and IGFBP-3 (6-8) have all been shown to suppress FSH-supported cAMP generation, steroidogenesis, and thymidine incorporation at the level of the murine granulosa cell.

To further evaluate the functional role of granulosa cellderived IGFBPs, we have taken advantage of the unique properties of a truncated analogue of IGF-I the ability of which to recognize and bind IGFBP-1, IGFBP-2, but not IGFBP-3 (9, 10 ) has been substantially diminished. Specifically, reference is made to des(1-3)IGF-I, a naturally occurring (presumptively posttranslationally modified) IGF-I analogue (11-14) lacking the amino-terminal tripeptide Gly-Pro-Glu. Indeed, des(13)IGF-I (but not intact IGF-I) binding to and activation of type I IGF receptors proved relatively impervious to inhibition by either IGFBP-1 $(9,13)$ or IGFBP-2 (9). Although a poor ligand of IGFBPs, des(1-3)IGF-I is functionally equivalent to IGF-I as a ligand of type I IGF receptors in some (15-17) but not all $(12,13,18)$ tissues. Consequent to this constellation of attributes, des(1-3)IGF-I is substantially more potent than its intact counterpart in stimulating the growth of a variety of cell types $(9-10,12,14,15)$.

Implicit in the present experimental approach is the prediction that truncated IGF-I would prove functionally superior to its intact counterpart when assessed under IGFBP-replete circumstances, a functional advantage attributable to relatively limited affinity for endogenously generated IGFBPs. Such observations would be in keeping with the notion that granulosa cell-derived IGFBPs are inhibitory to IGF-I hormonal action. On the other hand, equipotency of des(1-3)IGF-I and IGF-I under comparable experimental circumstances would render such possibility unlikely.

\section{Methods}

Animals. Immature (23-25-d old) Sprague-Dawley female rats from Johnson Laboratories Inc. (Bridgeview, IL) were implanted subcutane- 
ously with Silastic capsules containing diethylstilbestrol (DES) and killed between 3 and $4 \mathrm{~d}$ after surgery.

Reagents and hormones. McCoy's 5a medium (modified, without serum), penicillin-streptomycin solution, L-glutamine, and trypan blue stain $(0.4 \%$; wt $/ \mathrm{vol})$ were obtained from Grand Island Biological Co. (Grand Island, NY). Polyethylene glycol (PEG) 8000 was from Sigma Chemical Co. (St. Louis, MO). Human immune globulin (18\%) was from Cutter Biological (Berkeley, CA). The Centriprep Centrifugal Microconcentrator was from Amicon, a division of W. R. Grace \& Co. (Beverly, MA).

des(1-3)IGF-I with a sequence identical to human IGF-I but with the amino-terminal tripeptide omitted, was prepared by chemical synthesis (15), or by recombinant DNA technology in collaboration with Kabigen AB, Stockholm, Sweden (19). Recombinant [Gln ${ }^{3}, \mathrm{Ala}^{4}$, $\mathrm{Tyr}^{15}$, Leu ${ }^{16}$ ]IGF-I (20), generously provided by Drs. M.L. Bayne and M.A. Cascieri (Merck, Sharp \& Dohme, Rahway, NJ) represents partial simulation of the B-chain of insulin wherein two of the known three sequence-unique domains were replaced (i.e., residues -1 to 4 and residues 15 and 16). [ $\mathrm{Thr}^{59}$ ] IGF-I prepared from an Escherichia coli host by recombinant DNA procedures was from Amgen Biologicals (Thousand Oaks, CA). Synthetic IGF-II was generously provided by Dr. C.H. Li, University of California at San Francisco (San Francisco, CA). Ovine FSH (oFSH; NIH FSH-S14; FSH potency = 9 NIH FSHS1 U/mg; LH activity, $0.02 \mathrm{NIH}$ LH-S1 U/mg; PRL activity, $<0.1 \%$ by weight) was from the National Pituitary Agency, National Institute of Arthritis, Diabetes, and Digestive and Kidney Diseases.

Tissue culture procedures. Granulosa cells were maintained in culture for up to $72 \mathrm{~h}$ under serum-free conditions as previously described (1-5). At no point was serum used during the culture period.

Determination of IGF binding activity. The unoccupied binding protein content of conditioned and unconditioned media determined by measuring its ability to bind [ $\left.{ }^{125} \mathrm{I}\right] \mathrm{IGF}$ by a modification of previously described methodology (21). Samples were incubated for $1 \mathrm{~h}$ at $37^{\circ} \mathrm{C}$ with the indicated amount of [ ${ }^{125} \mathrm{I}$ ] IGF in $250 \mu$ l of McCoy's 5a medium stably buffered with Hepes at a $\mathrm{pH}$ of 7.4. Preliminary validation studies ( not shown) revealed concentrations of $\geq 20 \%$ of PEG to be required for maximal precipitation of the $\left[{ }^{125}\right.$ I] IGF-I-binding protein complex. Validation of time requirements revealed time-dependent increments in binding peaking after a $1-\mathrm{h}$ preincubation (not shown). Optimal precipitation of binding activity, although apparent at $22^{\circ} \mathrm{C}$, remained unchanged at $37^{\circ} \mathrm{C}$ in keeping with earlier reports from this laboratory (2). Accordingly, the IGF-binding protein complex formed was precipitated at $1,200 \mathrm{~g}$ for $15 \mathrm{~min}$ with $250 \mu \mathrm{l}$ of a $1 \%$ solution of human Ig and $500 \mu$ l of $25 \%$ PEG. The resultant pellet was washed once with $1 \mathrm{ml}$ of $6.25 \%$ PEG and centrifuged again. Bound [ $\left.{ }^{125} \mathrm{I}\right] \mathrm{IGF}$ was determined by counting the pellet. Nonspecific binding was determined using buffer alone supplemented with $1 \mu \mathrm{g} /$ tube of unlabeled IGF. Specifically bound $\left[{ }^{125}\right.$ I] IGF was expressed in terms of percentage of total binding.

Western ligand blots. Conditioned media were electrophoresed on SDS-PAGE (10\%) under nonreducing conditions. The size-fractionated proteins were then electroblotted onto nitrocellulose for $1 \mathrm{~h}$. Thereafter, the filter-immobilized proteins were blocked, incubated with 1 $\times 10^{6} \mathrm{cpm}$ of $\left[{ }^{125} \mathrm{I}\right]$ IGF-II overnight at $4^{\circ} \mathrm{C}$, washed, and visualized by autoradiography, according to the method of Hossenlopp et al. (22).

Radioligand receptor assays. Binding studies were conducted as previously described (23). Briefly, isolated granulosa cells were homogenized and spun at $600 \mathrm{~g}$ for $20 \mathrm{~min}$ at $4^{\circ} \mathrm{C}$. The first supernatant in turn was spun at $40,000 \mathrm{~g}$ for $20 \mathrm{~min}$ at $4^{\circ} \mathrm{C}$ to yield crude plasma membrane preparations. The latter were then incubated with $10^{5} \mathrm{cpm} /$ tube of [ ${ }^{125}$ I] IGF and the indicated concentration of the specified experimental agents. At the conclusion of the incubation period, the mixtures (total vol of $0.2 \mathrm{ml}$ ) were washed twice with $3 \mathrm{ml}$ ice-cold assay buffer to remove excess unbound hormone, and the cell-bound radioactivity in the final pellet determined using a gamma-spectrometer with a counting efficiency of $60 \%$. Nonspecific binding, determined using [ $\mathrm{Thr}^{59}$ ] IGF-I ( $1 \mu \mathrm{g} /$ tube $)$, constituted $1.9 \%$ of the total counts added or $9.6 \%$ of the total binding (23).
$R I A$. Medium progesterone content was determined using a specific antiserum (\#337) raised again progesterone-11-BSA (24), generously provided by Dr. Gordon D. Niswender (Colorado State University, Fort Collins, CO).

Data analysis. Statistical significance was determined by the Student's paired two-tailed $t$ test or analysis of variance as indicated.

\section{Results}

To validate the functional utility of des(1-3)IGF-I in the context of granulosa cell-derived IGFBPs, use was made of (IGFBP-containing) media conditioned by untreated cultured rat granulosa cells from immature DES-primed rats. Although the exact identity of rat granulosa cell-derived IGFBPs remains unknown, published information indicates the absence of IGFBP-2 (25). As shown (Fig. 1, left), addition of increasing concentrations $(0-1,000 \mathrm{ng} /$ tube $)$ of IGF-I resulted in progressive dose-dependent inhibition of specifically bound [ ${ }^{125}$ I] IGF$\mathrm{I}\left(\mathrm{IC}_{50}=0.5 \pm 0.07 \mathrm{ng} /\right.$ tube $)$. In contradistinction, des $(1-$ 3)IGF-I displayed substantially diminished competitive potency over the same dose range. Qualitatively similar results were obtained when using [ ${ }^{125}$ I] IGF-II (Fig. 1, right). As such, these observations indicate that truncated IGF-I possesses substantially diminished avidity for granulosa cell-derived IGFBPs as compared with the intact principle, thereby validating its utility in this experimental system.

To determine the relative affinities of des(1-3)IGF-I (and its intact counterpart) for untreated and FSH-treated rat granulosa cell type I and type II IGF receptors, use was made of a conventional radioligand receptor assay of corresponding membrane preparations. As shown (Fig. 2, left), des( 1-3)IGFI proved virtually equipotent to IGF-I in competing for binding to untreated $(A)$ or $\mathrm{FSH}(10$ or $100 \mathrm{ng} / \mathrm{ml})$-treated ( $B$ and $C$, respectively) rat granulosa cell $\left[{ }^{125} \mathrm{I}\right] \mathrm{IGF}-\mathrm{I}$ recognition sites. des(1-3) IGF-I displayed lesser avidity $\left(\mathrm{IC}_{50} \geq 100 \mathrm{ng} / \mathrm{ml}\right.$ ) for untreated $(A)$ or $\mathrm{FSH}(10$ or $100 \mathrm{ng} / \mathrm{ml})$-treated $(B$ and $C$,

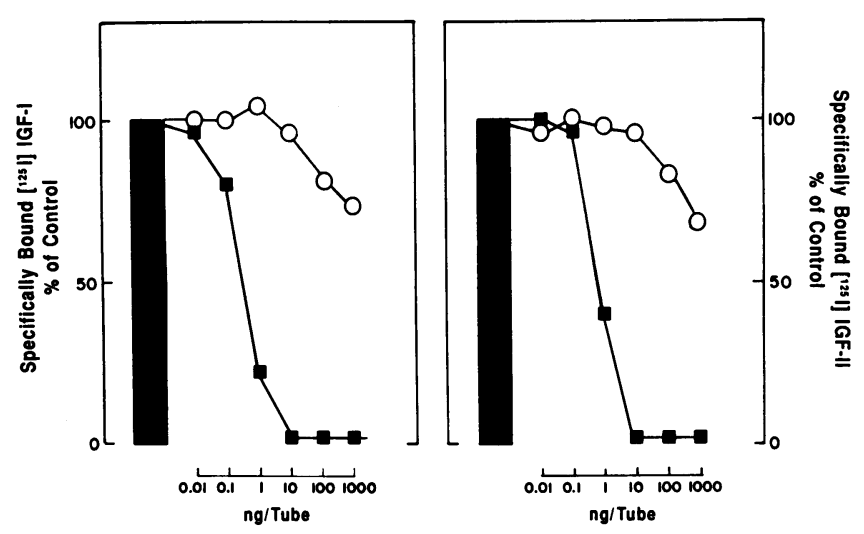

Figure 1. Functional validation of des(1-3)IGF-I. Competition for binding to granulosa cell-derived IGFBPs as assessed in a standardized PEG precipitation assay. Control (untreated) media conditioned by granulosa cells $\left(5 \times 10^{5}\right.$ cells/culture) were incubated for $1 \mathrm{~h}$ at $37^{\circ} \mathrm{C}$ with $2 \times 10^{4} \mathrm{cpm}$ of $\left[{ }^{125} \mathrm{I}\right] \mathrm{IGF}$ in $250 \mu \mathrm{l}$ of assay buffer in the absence or presence of increasing concentrations $(0.01-1,000 \mathrm{ng} / \mathrm{ml})$ of IGF-I or des(1-3)IGF-I. Specifically bound [ ${ }^{125}$ I]IGF was expressed in terms of percentage of control binding as described in Methods. $($ Left $)$ Tracer $=\left[{ }^{125}\right.$ I $]$ IGF-I. $($ Right $)$ Tracer $=\left[{ }^{125}\right.$ I $]$ IGF-II. The results reflect a representative experiment. Qualitatively comparable results were obtained in two additional identical experiments. $\square$, IGF-I; O, des( 1-3)IGF-I. 


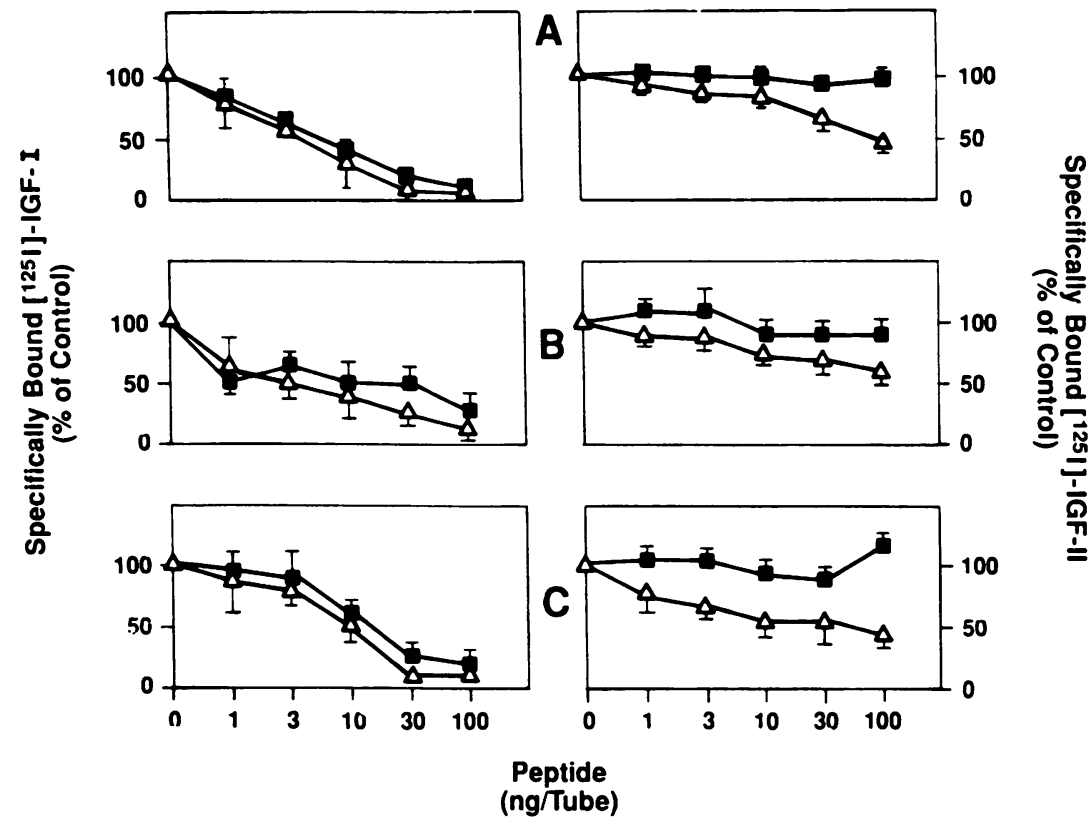

Figure 2. Functional Validation of des( 1-3)IGF-I. Competition for binding to untreated and FSHtreated rat granulosa cell type I and type II IGF receptors as assessed in conventional radioligand receptor assays. Isolated granulosa cell membranes were incubated with $10^{5} \mathrm{cpm} /$ tube of $\left[{ }^{125} \mathrm{I}\right] \mathrm{IGF}$ and the indicated concentrations of the specified experimental agents. Incubation and termination were as described in Methods. (Left) Type I IGF radioreceptor assay. (Right) Type II IGF radioreceptor assay. $\mathrm{A}, \mathrm{B}$, and $\mathrm{C}$ represent membranes from granulosa cells treated in the absence $(A)$ or presence of $10 \mathrm{ng} / \mathrm{ml}(B)$ or $100 \mathrm{ng} / \mathrm{ml}(C)$ of

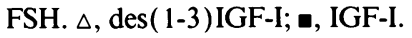

respectively) rat granulosa cell [ ${ }^{125}$ I] IGF-II recognition sites (Fig. 2, right). Taken together, these observations are compatible with the notion that the comparable avidity of des(13)IGF-I and IGF-I for rat granulosa cell type I IGF receptors remains unchanged after treatment with either 10 or $100 \mathrm{ng} /$ $\mathrm{ml}$ of FSH.

To examine the functional impact of des( 1-3)IGF-I, granulosa cells were cultured in the absence or presence of a minimally effective dose of FSH $(10 \mathrm{ng} / \mathrm{ml})$, with or without increasing concentrations $(0.3-50 \mathrm{ng} / \mathrm{ml})$ of either IGF-I or its truncated counterpart. Importantly, treatment with FSH concentrations at the $10 \mathrm{ng} / \mathrm{ml}$ dose level was designed (and herein confirmed) to be associated with little or no change in the elaboration of endogenous IGFBPs ( 3 ) as assessed by both PEG precipitation and ligand blotting (Fig. 3). Given these

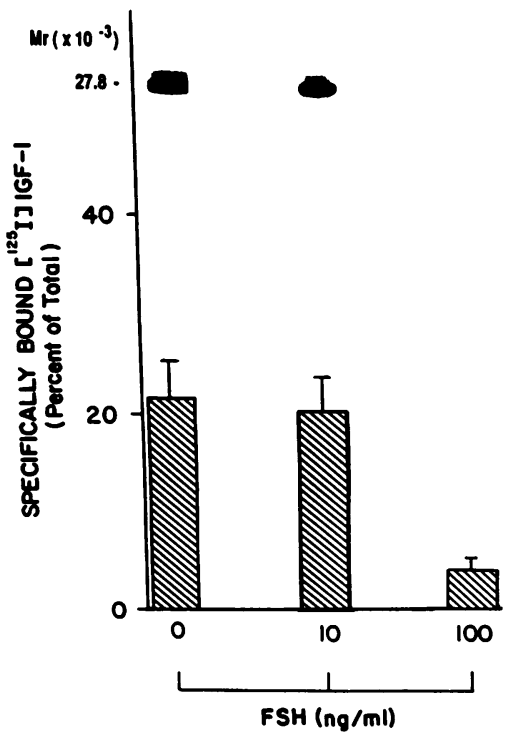

Figure 3. Effect of treatment with FSH on granulosa cell-derived IGFBP release. Dose dependence. Granulosa cells $\left(5 \times 10^{5}\right.$ cells $/$ culture) from immature DES-primed rats were grown under serum-free conditions for $72 \mathrm{~h}$ in the absence or presence of FSH at the 10 or 100 $\mathrm{ng} / \mathrm{ml}$ dose levels. The unoccupied IGF-I binding activity of conditioned media was determined by PEG-precipitation as described in Methods (lower panel). SDS-PAGE-fractionated media were subjected to Western ligand blotting as described in Methods (top panel). The data reflect a representative experiment. Qualitatively comparable results were obtained in two additional identical experiments.
IGFBP-replete circumstances, treatment with increasing concentrations of IGF-I resulted in progressive dose-dependent $\left(\mathrm{ED}_{50}=4.2 \pm 0.8 \mathrm{ng} / \mathrm{ml}\right)$ amplification of FSH hormonal action as assessed in terms of the overall accumulation of progesterone (Fig. 4). Comparable studies using des(1-3)IGF-I revealed the truncated analogue $\left(\mathrm{ED}_{50}=0.44 \pm 0.06 \mathrm{ng} / \mathrm{ml}\right)$ to be 10 -fold more potent than its native counterpart.

To exclude the possibility that des(1-3)IGF-I may be acting via the type II IGF receptor (for which it displayed measur-

\section{IGFBP-REPLETE CONDITIONS}

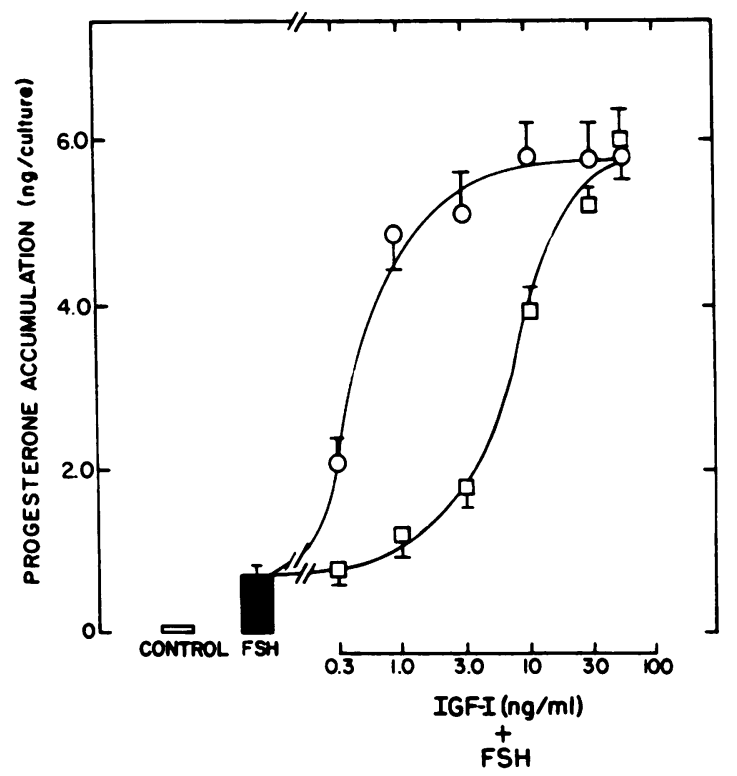

Figure 4. Effect of des(1-3)IGF-I or unmodified IGF-I on FSH hormonal action under IGFBP-replete conditions. Granulosa cells ( 1 $\times 10^{5}$ cells/culture) were grown under serum-free conditions for 72 $h$ in the absence or presence of FSH $(10 \mathrm{ng} / \mathrm{ml})$, with or without increasing concentrations $(0.3-50 \mathrm{ng} / \mathrm{ml})$ of either IGF-I or its truncated counterpart. Medium progesterone content was determined by $\mathrm{RIA}$ as described in Methods. The results represent the mean $\pm \mathrm{SE}$ of three separate determinations. $\square$, IGF-I; O, des( 1-3) IGF-I. 
able affinity; Fig. 2, right), we have undertaken to repeat the experiment depicted in Fig. 4 in the presence of neutralizing concentrations $(100 \mu \mathrm{g} / \mathrm{ml})$ of R-II-PAB 1 , a previously validated (26) rat type II IGF receptor-directed monoclonal antibody (27). As shown (Fig. 5), qualitatively similar results were obtained (relative to R-II-PAB1-negative conditions; Fig. 4) thereby arguing against the possibility that the apparent advantage of des(1-3)IGF-I is accounted for by its ability to interact at the level of the rat granulosa cell type II IGF receptor.

Given that the apparent increase in potency displayed by des(1-3)IGF-I may be accounted for by its diminished affinity for endogenously derived IGFBPs, we have undertaken to reevaluate des(1-3)IGF-I action under experimental circumstances characterized by the absence of endogenously elaborated IGFBPs. To this end, use was made of a maximally effective dose of FSH $(100 \mathrm{ng} / \mathrm{ml})$, the ability of which to virtually eliminate the production of granulosa cell-derived IGFBPs was previously demonstrated $(1,3)$ and herein confirmed (Fig. 3 ). Ovarian granulosa cells were cultured for $72 \mathrm{~h}$ with or without FSH $(100 \mathrm{ng} / \mathrm{ml})$, in the absence or presence of increasing concentrations $(0.3-50 \mathrm{ng} / \mathrm{ml})$ of either IGF-I or its des(13)IGF-I analogue. As shown (Fig. 6), both des( 1-3)IGF-I and its intact counterpart displayed substantially increased potency $\left(E D_{50}=0.6 \pm 0.09 \mathrm{ng} / \mathrm{ml}\right)$ relative to that observed for native IGF-I under IGFBP-replete circumstances $\left(\mathrm{ED}_{50}=4.2 \pm 0.8\right.$ ng/ml; Fig. 4). However, des( 1-3)IGF-I proved virtually equi-

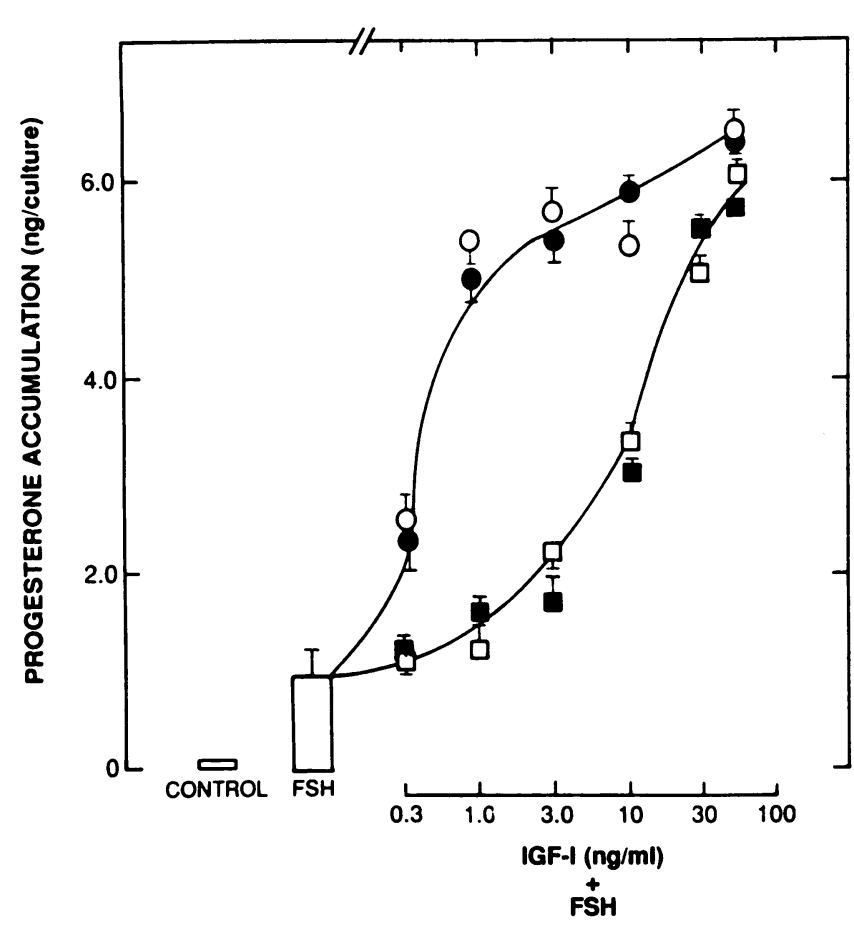

Figure 5. Effect of des(1-3)IGF-I or unmodified IGF-I on FSH hormonal action under IGFBP-replete conditions. Role of type II IGF receptors. R-II-PAB1 ( $100 \mu \mathrm{g} / \mathrm{ml})$-supplemented granulosa cells ( 1 $\times 10^{5}$ cells/culture) were grown under serum-free conditions for 72 $\mathrm{h}$ in the absence or present of FSH $(10 \mathrm{ng} / \mathrm{ml})$, with or without increasing concentrations $(0.3-50 \mathrm{ng} / \mathrm{ml})$ of either IGF-I or its truncated counterpart. Medium progesterone content was determined by RIA as described in Methods. The results represent the mean $\pm \mathrm{SE}$ of three separate determinations. $\square$, IGF-I; $\circ$, des(1-3)IGF-I; $\mathbf{m}$, IGF-I + R-II-PAB1; •, des(1-3)IGF-I + RII-PAB1.

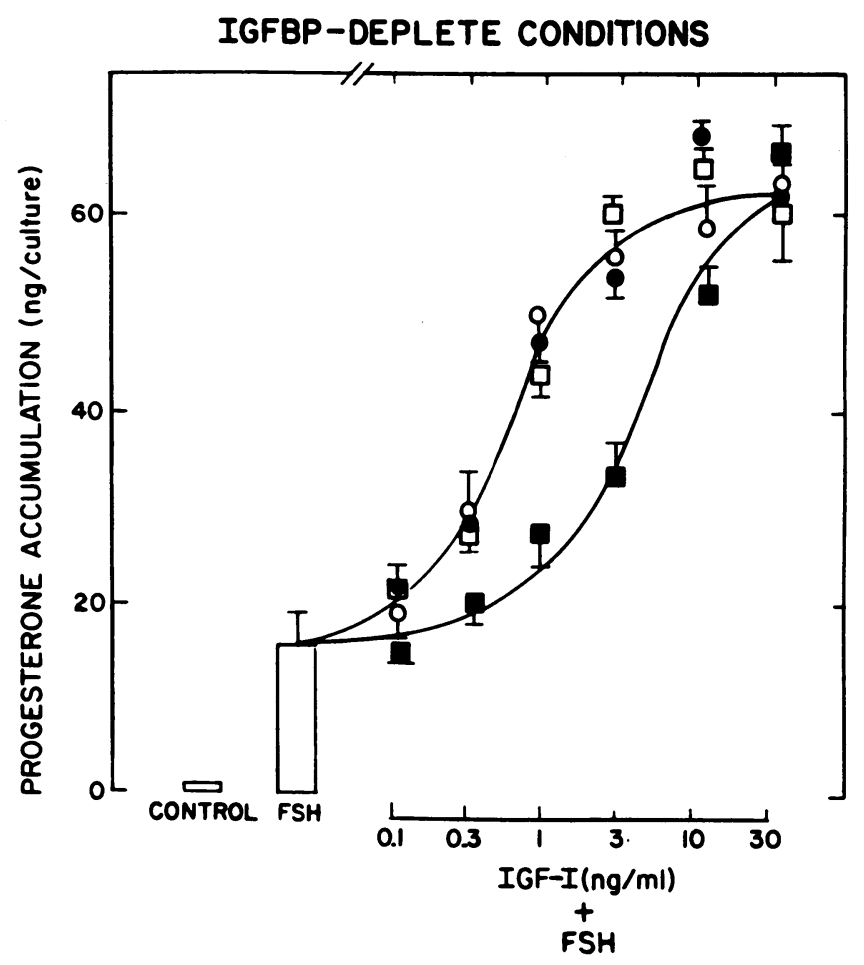

Figure 6. Effect of des(1-3)IGF-I or unmodified IGF-I on FSH hormonal action under IGFBP-deplete conditions. Granulosa cells ( 1 $\times 10^{5}$ cells/culture) were cultured under serum-free conditions for $72 \mathrm{~h}$ in the absence or presence of FSH $(100 \mathrm{ng} / \mathrm{ml})$, with or without increasing concentrations $(0.1-30 \mathrm{ng} / \mathrm{ml})$ of either IGF-I or its truncated counterpart. A parallel set of experiments was carried out in the presence of CM, i.e., Amicon. (10,000)-filtered content of media ( 1 $\mathrm{ml})$ conditioned by low concentrations of FSH $(10 \mathrm{ng} / \mathrm{ml})$. Medium progesterone content was determined by RIA as described in Methods. The results represent the mean $\pm \mathrm{SE}$ of three separate determinations. $\square$, IGF-I; o, des( 1-3) IGF-I; $\bullet$, IGF-I + CM; •, des( 1-3) IGF-I $+\mathrm{CM}$.

potent to the unmodified principle, thereby strongly suggesting that the apparently enhanced potency of des(1-3)IGF-I (under IGFBP-replete conditions) is due to its diminished affinity for endogenously generated IGFBPs. As such, these findings are in keeping with the notion that endogenously derived IGFBPs are inhibitory to IGF-mediated amplification of FSH-supported progesterone biosynthesis hormonal action. This conclusion was further supported by experiments wherein the addition of the amicon-filtered content of media (CM; $1 \mathrm{ml}$ ) conditioned by low concentrations ( $10 \mathrm{ng} / \mathrm{ml}$ ) of FSH (IGFBP-replete media) effectively attenuated IGF-I hormonal action (Fig. 6) while reaffirming the apparent edge of des(1-3)IGF-I in this context. The amicon filter mol wt cutoff $(10,000)$ ensured trapping of IGFBPs while eliminating steroidal principles, the retention of which could have rendered the results uninterpretable. Indeed, no immunoreactive progesterone could be detected in amicon-filtered media (not shown).

To ensure that the preceding observations are not des(13)IGF-I-specific, we have undertaken to carry out comparable studies with a similarly endowed analogue. Specifically, the ability of $\left[\mathrm{Gln}^{3}, \mathrm{Ala}^{4}, \mathrm{Tyr}^{15}\right.$, Leu $\left.{ }^{16}\right] \mathrm{IGF}-\mathrm{I}$ to compete for binding to media conditioned by untreated cultured granulosa cells was evaluated in a standardized PEG-precipitation assay. When using [ $\left.{ }^{125} \mathrm{I}\right] \mathrm{IGF}-\mathrm{I}$ (Fig. 7, left), [Gln ${ }^{3}, \mathrm{Ala}^{4}, \mathrm{Tyr}^{15}$, 


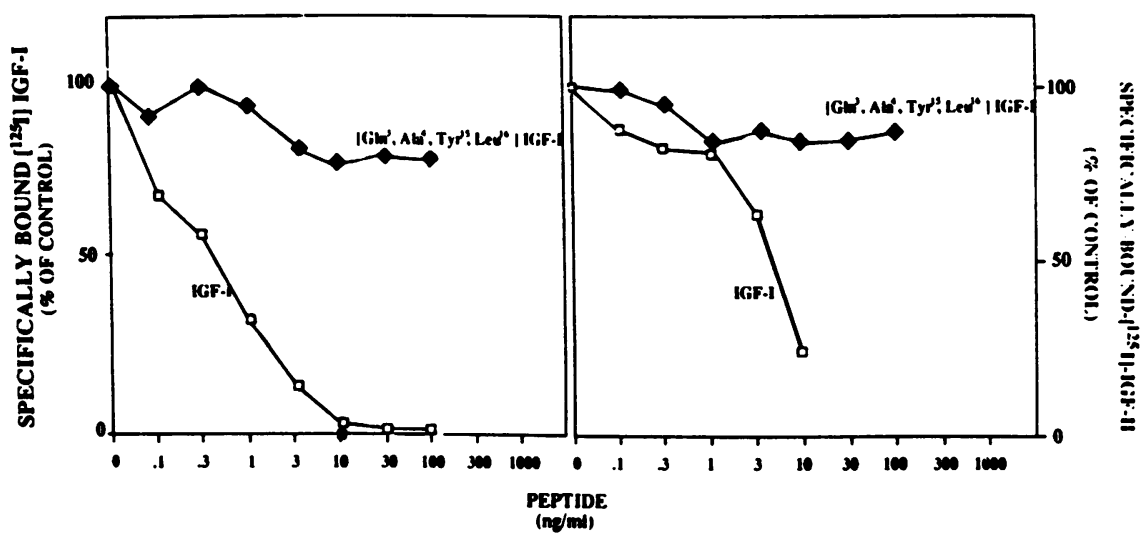

Figure 7. $\left[\mathrm{Gln}^{3}, \mathrm{Ala}^{4}, \mathrm{Tyr}^{15}\right.$, Leu $\left.{ }^{16}\right]$ IGF-I. Competition for binding to granulosa cell-derived IGFBPs as assessed in a standardized PEG precipitation assay. Media conditioned by untreated cultured granulosa cells was incubated for $1 \mathrm{~h}$ at $37^{\circ} \mathrm{C}$ with $2 \times 10^{4} \mathrm{cpm}$ of [ ${ }^{125}$ I] IGF in $250 \mu$ l of assay buffer in the absence or presence of increasing concentrations of IGF-I $(0.1-10 \mathrm{ng} / \mathrm{ml})$, or [ $\left[\mathrm{Gln}^{3}, \mathrm{Ala}^{4}\right.$, $\mathrm{Tyr}^{15}$, Leu ${ }^{16}$ ]IGF-I ( $\left.10-100 \mathrm{ng} / \mathrm{ml}\right)$. Specifcally bound [ ${ }^{125}$ I] IGF-I was expressed in terms of percentage of control binding as described in Methods. $($ Left $)$ Tracer $=\left[{ }^{125} \mathrm{I}\right]$ IGF-I. (Right) Tracer $=\left[{ }^{125}\right.$ I]IGF-II. The results reflect a representative experiment. Qualitatively comparable results were obtained in two additional identical experiments.
Leu ${ }^{16}$ ]IGF-I displayed substantially diminished affinity for granulosa cell-derived IGFBPs as compared with the unmodified principle. Qualitatively similar results were obtained when using [ ${ }^{125}$ I] IGF-II (Fig. 7, right). In related studies, we have also undertaken to determine the relative affinity of the analogue for rat granulosa cell type I and type II IGF receptors. As shown (Fig. 8, left), [Gln ${ }^{3}, \mathrm{Ala}^{4}, \mathrm{Tyr}^{15}$, Leu $\left.{ }^{16}\right] \mathrm{IGF}-\mathrm{I}$ proved virtually equipotent to IGF-I in competing for binding to rat granulosa cell [ $\left.{ }^{125} \mathrm{I}\right] \mathrm{IGF}-\mathrm{I}$ recognition sites. In contrast, the analogue proved relatively ineffective in terms of its ability to compete for binding to rat granulosa cell [ $\left.{ }^{125} \mathrm{I}\right] \mathrm{IGF}-\mathrm{II}$ recognition sites (Fig. 8; right).

To examine the functional impact of the $\left[\mathrm{Gln}^{3}, \mathrm{Ala}^{4}\right.$, $\mathrm{Tyr}^{15}$, Leu ${ }^{16}$ ]IGF-I analogue, granulosa cells were cultured in the absence or presence of a minimally effective dose of FSH $(10 \mathrm{ng} / \mathrm{ml})$, with or without increasing concentrations $(0.3-50$ $\mathrm{ng} / \mathrm{ml}$ ) of either IGF-I or its analogues. As shown (Fig. 9, left), $\left[\mathrm{Gln}^{3}, \mathrm{Ala}^{4}, \mathrm{Tyr}^{15}\right.$, Leu $\left.{ }^{16}\right] \mathrm{IGF}-\mathrm{I}\left(\mathrm{ED}_{50}=0.8 \pm 0.2 \mathrm{ng} / \mathrm{ml}\right)$ proved substantially (five to six times) more potent than its counterpart when tested under IGFBP-replete circumstances. This apparent edge was lost, however, when restudied under IGFBP-deplete circumstances (Fig. 9, right). As such, these findings suggest that the apparently enhanced potency of $\left[\mathrm{Gln}^{3}, \mathrm{Ala}^{4}, \mathrm{Tyr}^{15}\right.$, Leu ${ }^{16}$ ]IGF-I (under IGFBP-replete conditions) is likely due to its diminished affinity for endogenously generated IGFBPs.

\section{Discussion}

IGFBPs are multifunctional proteins capable of binding IGFs (but not insulin) with affinities in the $10^{-10}-10^{-9} \mathrm{M}$ range that regulate not only the transport of IGFs but also their presentation to cognate cell surface receptors (28). Although the precise role(s) of tissue-derived IGFBPs is a matter of ongoing studies, both stimulation $(29,30)$ and inhibition $(31,32)$ of IGF binding and action have been reported. Thus, the synthesis and secretion of IGFBPs may play a major role in the regulation of IGF hormonal action at the target cell level.

Although the relevance of IGFBPs to ovarian physiology remains unknown, media conditioned by cultured murine granulosa cells were reported to contain IGF binding activity (1-3). One such species, IGFBP-1, was localized to luteinized human granulosa cells by immunohistochemistry $(33,34)$, radioimmunoassay $(34,35)$, immunoisolation (36), and Northern blotting (37). Other IGFBP species, i.e., IGFBP-2 and IGFBP-3, were localized to the porcine granulosa cell (38). In this communication, we seek to reevaluate the role of granulosa cell-derived IGFBPs as it relates to IGF-I hormonal action. Special attention has been paid to the possibility that granulosa cell-derived IGFBPs may inhibit IGF hormonal action, thereby compromising its ability to amplify the gonadotropic signal (4).

Validation of des(1-3)IGF-I revealed it to display substantially diminished affinity for granulosa cell-derived IGFBPs as compared with the native unmodified principle (Fig. 1). Although granulosa cell-derived IGFBPs clearly constitute a heterogenous mix of IGF binding species (1-3), this material nevertheless represents a more physiologic and thus a more relevant reference preparation. In this respect, our current observations are in keeping with those reported by others wherein the limited affinity of des(1-3)IGF-I to both IGFBP-1

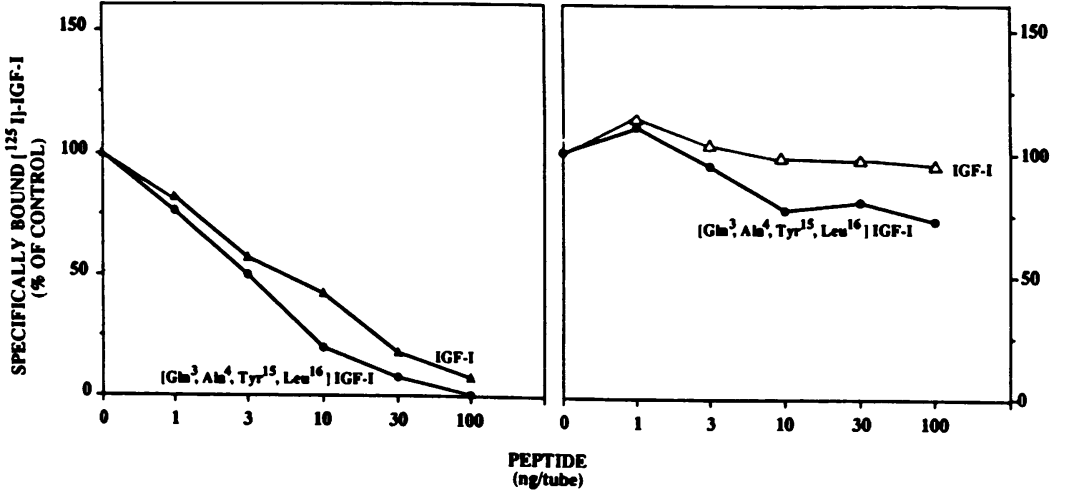

Figure 8. [ $\mathrm{Gln}^{3}, \mathrm{Ala}^{4}, \mathrm{Tyr}^{15}$, Leu $\left.{ }^{16}\right]$ IGF-I. Competition for binding to rat granulosa cell type I and type II IGF receptors as assessed in conventional radioligand receptor assays. Isolated granulosa cell membranes were incubated with $10^{5} \mathrm{cpm} /$ tube of [ $\left.{ }^{125} \mathrm{I}\right] \mathrm{IGF}$ and the indicated concentrations of the specified experimental agents. Incubation and termination were as described in Methods. The data reflect a representative experiment. Qualitatively comparable results were obtained in two additional identical experiments. (Left) Type I IGF receptor assay. (Right) Type II IGF receptor assay. 


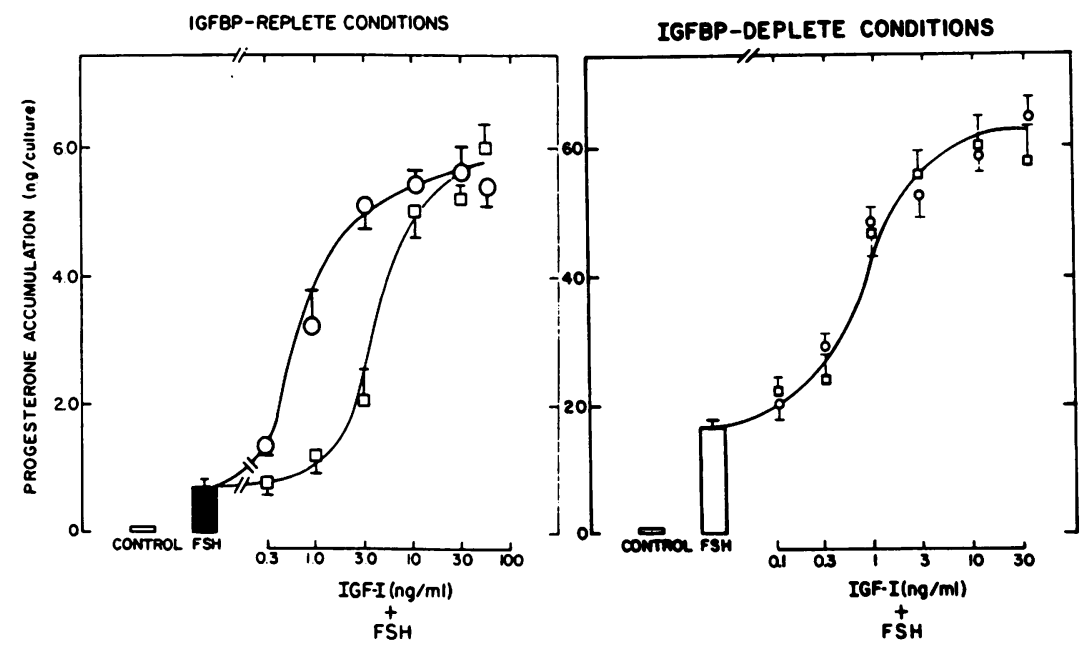

Figure 9. Effect of $\left[\mathrm{Gln}^{3}, \mathrm{Ala}^{4}, \mathrm{Tyr}^{15}, \mathrm{Leu}^{16}\right]$ IGF-I or unmodified IGF-I on FSH hormonal action under IGFBP-replete (left panel) or IGFBP-replete (right panel) conditions. Granulosa cells $\left(1 \times 10^{5}\right.$ cells/culture $)$ were grown under serum-free conditions for $72 \mathrm{~h}$ in the absence or presence of FSH $(10 \mathrm{ng} / \mathrm{ml}$ [left] or $100 \mathrm{ng} / \mathrm{ml}$ [right]) with or without increasing concentrations $(0.3-50 \mathrm{ng} / \mathrm{ml}$ [left] or $0.1-30 \mathrm{ng} / \mathrm{ml}$ [right $])$ of either IGF-I or its modified analogue. Medium progesterone content was determined by RIA as described in Methods. The results represent the mean \pm SE of three separate determinations. $\square$ IGF-I; O, $\left[\mathrm{Gln}^{3}, \mathrm{Ala}^{4}, \mathrm{Tyr}^{15}\right.$, Leu $\left.{ }^{16}\right]$ IGF-I.

and IGFBP-2 (but not IGFBP-3) has been clearly demonstrated $(9,10)$.

Our present findings further document that des(1-3)IGF-I effectively binds to type I IGF receptors (Fig. 2, left). Thus, given that the membranes in question are effectively devoid of IGFBPs (26), it is highly likely that des(1-3)IGF-I binding involved type I IGF receptors rather than contaminating IGFBPs. Accordingly, any functional differences between the truncated analogue and its native counterpart cannot be ascribed to differences in binding potencies to the type I IGF receptor. As such, these observations are in keeping with those reported by several investigators wherein des(1-3)IGF-I proved functionally equivalent to its intact counterpart in terms of binding to type I IGF receptors in some (15-17) but not all $(12,13,18)$ tissues and cells so studied. Our current observations (Fig. 2, right) also indicate that des(1-3)IGF-I (like intact IGF-I) displays relatively limited, albeit measurable, affinity for rat granulosa cell type II IGF receptors. It is not immediately apparent why des(1-3)IGF-I displayed increased affinity for type II IGF receptors as compared with its unmodified counterpart. All told, these findings suggest that des( 1-3)IGF-I (and its unmodified counterpart) effectively activate type I receptors. Although des(1-3)IGF-I may be in a position to bind type II IGF receptors, such a phenomenon is likely to prove functionally irrelevant in that IGF-I and IGF-II hormonal action at the level of the rat granulosa cell is exerted largely, if not exclusively, via type I IGF receptors (27). Experiments reported herein (Fig. 5) are in full agreement with this conclusion.

Having established des(1-3)IGF-I as a weak ligand of IGFBPs (but not of type I IGF receptors), we have undertaken to exploit this differential binding pattern to reevaluate the impact of granulosa cell-derived IGFBPs on IGF hormonal action. Initial experiments carried out under IGFBP-replete conditions clearly indicated that the truncated analogue is substantially more potent than its native unmodified counterpart in promoting FSH-supported progesterone accumulation (Fig. 4). Given that such differences cannot be accounted for by divergent interactions at the level of the type I IGF receptor (Fig. 2), it is highly likely that differences in binding affinity to endogenously derived IGFBPs are at play. As such, these findings are in keeping with the notion that endogenously derived IGFBPs are inhibitory to IGF hormonal action. This notion was further confirmed under experimental conditions charac- terized by the absence of endogenously elaborated IGFBPs. Indeed, given IGFBP-deplete conditions, des(1-3)IGF-I proved virtually equipotent to the unmodified native principle (Fig. 6). Qualitatively comparable observations (Fig. 9) made using a similarly endowed (Figs. 7 and 8 ) IGF-I analogue, i.e., $\left[\mathrm{Gln}^{3}, \mathrm{Ala}^{4}, \mathrm{Tyr}^{15}\right.$, Leu $\left.{ }^{16}\right]$ IGF-I.

Taken together, these findings indicate that granulosa cellderived IGFBPs are inhibitory to IGF-mediated amplification of FSH-supported progesterone biosynthesis. Moreover, given the established ability of IGFs to synergize with FSH in the promotion of granulosa cell differentiation (4), the present observations are also in keeping with the notion that granulosa cell-produced IGFBPs are in effect inhibitory to gonadotropin (FSH) hormonal action. Accordingly, FSH-attenuated IGFBP release $(1,3)$ may be designed to enhance the bioavailability and hence the access of endogenously generated IGFs to their cognate cell surface receptors, and in so doing, promote FSHsupported progesterone biosynthesis.

\section{Acknowledgments}

This work was supported in part by National Institutes of Health (NIH) research grant HD-19998 and Research Career Development Award HD-00697 to E. Y. Adashi, as well as NIH research grants DK28229 and CA-42106 to R. G. Rosenfeld.

\section{References}

1. Adashi, E. Y., C. E. Resnick, E. R. Hernandez, A. Hurwitz, and R. G. Rosenfeld. 1990. Follicle-stimulating hormone inhibits the constitutive release of insulin-like growth factor binding proteins by cultured rat ovarian granulosa cells. Endocrinology. 126:1305-1306.

2. Adashi, E. Y., C. E. Resnick, E. R. Hernandez, A. Hurwitz, and R. G. Rosenfeld. 1990. Ovarian granulosa cell-derived insulin-like growth factor (IGF) binding proteins: constitutive release of low molecular weight, high-affinity IGFselective species. Mol. Cell. Endocrinol. 74:175-185.

3. Adashi, E. Y., C. E. Resnick, A. Hurwitz, E. Ricciarelli, E. R. Hernandez, and R. G. Rosenfeld. 1991. Ovarian granulosa cell-derived insulin-like growth factor binding proteins: modulatory role of follicle-stimulating hormone. Endocrinology. 128:754-760.

4. Adashi, E. Y., C. E. Resnick, M. E. Svoboda, and J. J. Van Wyk. 1986. Somatomedin-C as an amplifier of follicle-stimulating hormone action: enhanced accumulation of adenosine 3',5'-cyclic monophosphate. Endocrinology. 118:149-156.

5. Adashi, E. Y., C. E. Resnick, E. Ricciarelli, A. Hurwitz, E. Kokia, L. Botero, C. Tedeschi, E. R. Hernandez, R. Koistinen, E. M. Ruitanen, and K. Seppala. 1992. Local tissue modification of follicle-stimulating hormone action. In Hor- 
mones in Gynecological Endocrinology. A. R. Genazzani and F. Petraglia, editors. Parthenon Publishing Group, Carnforth, Lancs., UK. pp. 255-261.

6. Ui, M., M. Shimonaka, S. Shimasaki, and N. Ling. 1989. An insulin-like growth factor-binding protein in ovarian follicular fluid blocks follicle-stimulating hormone-stimulated steroid production by ovarian granulosa cells. Endocrinology. 125:912-916.

7. Bicsak, T. A., M. Shimonaka, M. Malkowski, and N. Ling. 1990. Insulinlike growth factor binding protein (IGF-BP) inhibition of granulosa cell function effect of cyclic adenosine 3',5'-monophosphate, deoxyribonucleic acid synthesis, and comparison with the effect of an IGF-I antibody. Endocrinology. 126:21842189.

8. Shimasaki, S., M. Shimonaka, M. Ui, S. Inouye, F. Shibata, and N. Ling 1990. Structural characterization of a follicle-stimulating hormone action inhibitor in porcine ovarian follicular fluid. J. Biol. Chem. 265:2198-2202.

9. Ross, M., G. L. Francis, L. Szabo, J. C. Wallace, and F. J. Ballard. 1989. Insulin-like growth factor (IGF)-binding proteins inhibit the biological activities of IGF-I and IGF-II but not des(1-3)IGF-I. Biochem. J. 258:267-272.

10. Carlsson-Skwirut, C., M. Lake, M. Hartmanis, K. Hall, and V. R. Sara 1989. A comparison of the biological activity of the recombinant intact and truncated insulin-like growth factor I (IGF-I). Biochim. Biophys. Acta 1011:192-197.

11. Ogasawara, M., P. Karey, H. Marquardt, and D. A. Sirbasku. 1989. Identification and purification of truncated insulin-like growth factor I from porcine uterus. Biochemistry. 28:2710-2721.

12. Sara, V. R., C. Carlsson-Skwirut, C. Andersson, E. Hall, B. Sjogren, A Holmgren, and H. Jornvall. 1986. Characterization of somatomedins from human fetal brain: identification of a variant form of insulin-like growth factor I. Proc. Natl. Acad. Sci. USA. 83:4904-4907.

13. Carlsson-Skwirut, C., H. Jornvall, A. Holmgren, C. Andersson, T. Bergman, G. Lundquist, B. Sjogren, and V. R. Sara. 1986. Isolation and characterization of variant IGF-2 as well as IGF-2 from adult human brain. FEBS(Fed. Eur. Biochem. Soc.) Lett. 201:46-50.

14. Francis, G. L., L. C. Read, F. J. Ballard, C. J. Bagley, F. M. Upton, P. M. Gravestock, and J. C. Wallace. 1986. Purification and partial sequence analysis of insulin-like growth factor-1 from bovine colostrum. Biochem. J. 233:207-213.

15. Ballard, F. J., G. L. Francis, M. Ross, C. J. Bagley, B. May, and J. C. Wallace. 1987. Natural and synthetic forms of insulin-like growth factor-I (IGFI) and the potent derivative destripeptide IGF-I: biological activities and receptor binding. Biochem. Biophys. Res. Commun. 149:398-404.

16. McKinnon, P., M. Ross, J. R. E. Wells, F. J. Ballard, and G. L. Francis 1991. Expression, purification and characterization of secreted recombinant human insulin-like growth factor-I (IGF-I ) and the potent variant des( 1-3)IGF-I in Chinese hamster ovary cells. J. Mol. Endocrinol. 6:231-239.

17. Canalis, E., T. L. McCarthy, and M. Centrella. 1991. Effects of desamino(1-3)-insulin-like growth factor I on bone cell function in rat calvarial cultures. Endocrinology. 129:534-541.

18. Ballard, J., M. Ross, F. M. Upton, and G. L. Francis. 1988. Specific binding of insulin-like growth factors 1 and 2 to the type 1 and type 2 receptors respectively. Biochem. J. 249:721-726.

19. Moks, T., L. Abrahmsen, E. Holmgren, M. Billich, A. Olsson, M. Uhlen, G. Pohl, C. Sterky, H. Hultberg, S. Josephson, et al. 1987. Expression of human insulin-like growth factor-1 in bacteria: use of optimized gene fusion vectors to facilitate protein purification. Biochemistry. 26:5239-5244.

20. Bayne, M. L., J. Applebaum, G. G. Chicchi, N. S. Hayes, B. G. Green, and M. A. Cascieri. 1988. Structural mutants of human insulin-like growth factor I with reduced affinity for the serum binding proteins and the type 2 IGF receptor. J. Biol. Chem. 263:6233-6239.

21. McCusker, R. H., and D. R. Clemmons. 1988. Insulin-like growth factor binding protein secretion by muscle cells: effect of cellular differentiation and proliferation. J. Cell. Physiol. 137:505-512.

22. Hossenlopp, P., D. Seurin, B. Segovia-Quinson, S. Hardouin, and M. Binoux. 1986. Analysis of serum insulin-like growth factor binding proteins using western blotting: use of the method for titration of the binding proteins and competitive binding studies. Anal. Biochem. 154:138-143.

23. Adashi, E. Y., C. E. Resnick, E. R. Hernandez, M. E. Svoboda, and J. J. Van Wyk. 1988. Characterization and regulation of specific cell membrane receptor for somatomedin-C/insulin-like growth factor I in cultured rat granulosa cells. Endocrinology. 122:194-201.

24. Gibori, G., E. Antczak, and I. Rothchild. 1977. The role of estrogen in the regulation of luteal progesterone secretion in the rat after day 12 of pregnancy. Endocrinology. 100:1483-1495.

25. Ricciarelli, E., E. R. Hernandez, A. Hurwitz, E. Kokia, R. G. Rosenfeld, J. Schwander, and E. Y. Adashi. 1991. The ovarian expression of the antigonadotropic insulin-like growth factor binding protein-2 is theca-interstitial cell-selective: evidence for hormonal regulation. Endocrinology. 129:2266-2268.

26. Adashi, E. Y., C. E. Resnick, and R. G. Rosenfeld. 1990. Insulin-like growth factor-I (IGF-I) and IGF-II hormonal action in cultured rat granulosa cells: mediation via type I but not type II IGF receptors. Endocrinology. 126:216222.

27. Rosenfeld, R. G., and H. Pham. 1987. Production of monoclonal antibodies to the rat insulin-like growth factor II (IGF-II) receptor. Biochem. Biophys. Res. Commun. 146:717-724.

28. Rutanen, E. M., and F. Pekonen. 1990. Insulin-like growth factors and their binding proteins. Acta Endocrinol. 123:7-13.

29. Clemmons, D. R., R. G. Elgin, V. K. M. Han, S. J. Casella, A. J. D’Ercole, and J. J. Van Wyk. 1986. Cultured fibroblast monolayers secrete a protein that alters the cellular binding of somatomedin-C/insulin-like growth factor I. J. Clin. Invest. 77:1548-1556.

30. De Vroede, M. A., L. Y. H. Tseng, P. G. Katsoyannis, S. P. Nissley, and M. M. Rechler. 1986. Modulation of insulin-like growth factor I binding to human fibroblast monolayer cultured by insulin-like growth factor carrier proteins released to the incubation media. J. Clin. Invest. 77:602-613.

31. Rutanen, E. M., F. Pekonen, and T. Makinen. 1988. Soluble 34K binding protein inhibits the binding of insulin-like growth factor I to its cell receptors in human secretory phase endometrium: evidence for autocrine/paracrine regulation of growth factor action. J. Clin. Endocrinol. \& Metab. 66:173-180.

32. Perkel, V. S., S. Mohan, D. J. Baylink, and T. A. Linkhart. 1990. An inhibitory insulin-like growth factor binding protein (IN-IGFBP) from human prostatic cell conditioned medium reveals $\mathrm{N}$-terminal sequence identify with bone derived IN-IGFBP. J. Clin. Endocrinol. \& Metab. 71:533-535.

33. Seppala, M., T. Wahlstrom, A. I. Koskimies, A. Tenhunen, E. M. Rutanen, R. Koistinen, I. Huhtaniemi, H. Bohn, and U. H. Stenman. 1984. Human preovulatory follicular fluid, luteinized cells of hyperstimulated preovulatory follicles, and corpus luteum contain placental protein 12. J. Clin. Endocrinol. \& Metab. 58:505-510.

34. Hartshorne, G. M., S. C. Bell, and G. T. Waites. 1990. Binding proteins for insulin-like growth factors in the human ovary: identification, follicular fluid levels and immunohistological localization of the 29-32kd type 1 binding protein, IGF-bpl. Hum. Reprod. (Eynsham). 5:649-660.

35. Suikkari, A. M., J. Jalkanen, R. Koistinen, R Butzow, O. Ritvos, T Ranta, and M. Seppala. 1989. Human granulosa cells synthesize low molecular weight insulin-like growth factor-binding protein. Endocrinology. 124:10881090.

36. Jalkanen, J., A. M. Suikkari, R. Koistinen, R. Butzow, O. Ritvos, M. Seppala, and T. Ranta. 1989. Regulation of insulin-like growth factor-binding protein-1 production in human granulosa-luteal cells. J. Clin. Endocrinol. \& Metab. 69:1174-1179.

37. Koistinen, R., A. M. Suikkari, A. Tiitinen, K. Kontula, and M. Seppala. 1990. Human granulosa cells contain insulin-like growth factor binding protein (IGF BP-1) mRNA. Clin. Endocrinol. 32:635-640.

38. Mondschein, J. S., S. A. Smith, and J. M. Hammond. 1990. Production of insulin-like growth factor binding proteins (IGFBPs) by porcine granulosa cells: identification of IGFBP- 2 and -3 and regulation by hormones and growth factors. Endocrinology. 127:2298-2306. 